Frederick J. Carlock MD, Morris Brown MD, Eli M. Brown MD

\title{
Isoflurane anaesthesia for a patient with long Q-T syndrome
}

A case report of a patient known to have long $Q-T$ syndrome (LQTS) undergoing elective oral surgery is presented. While nitrous oxide-narcotic, nitrous axideenflurane, or nitrous oxide-halothane techniques for anaesthetic management of LQTS have been previously reported, we report the use of nitrous axide-isoflurane for the maintenance of anaesthesia. The authors feel that isoflurane is a safe anaesthetic agent for use in LQTS.

Key words

HEART: long Q-T syndrome, electrocardiography; ANAESTHETICS, VOLATILE: isofurane; SURGERY: oral.

Congenital long Q-T syndrome (LQTS) with syncopal episodes secondary to ventricular tachyarrhythmias following emotional or physical stress has been described. 'Ventricular tachyarrhythmias typically follow stimulation of the sympathetic nervous system secondary to stress, including the stress of anaesthesia and surgery. Indeed, unrecognized or improperly managed congenital LQTS may lead to intraoperative ventricular tachyarthyth. mias and even death. ${ }^{2}$

Although extensive medical literature on LQTS exists, ' descriptions of anaesthetic management are limited. Review of the literature indicates there have been only seven patients reported with this syndrome who have received anaesthesia..$^{2-7}$ These patients have been managed with nitrous oxideenflurane, nitrous oxide-halothane, and nitrous

From the Department of Anesthesiology, Sinai Hospital of Detroit, Detroit, Michigan.

Address correspondence w: Dr. Morris Brown, Director of Critical Care Services, Sinai Hospital of Detroit, 6767 W. Outer Drive, Detroit, Michigan 48235 . oxide-narcotic techniques. The following case is, to our knowledge, the first report of a patient with LQTS anaesthetized with isoflurane.

\section{Case report}

A twenty-seven-year-old woman was scheduled for elective mandibular osteotomy. The diagnosis of LQTS was made three years prior to admission after the patient presented with a history of syncopal episodes since childhood. The patient had been well controlled on propranolol and diphenylhydantoin for three years. Three family members had LQTS with one death from the syndrome. There was no personal or family history of deafness. Electrocardiograms prior to admission documented long Q-T intervals with episodes of ventricular tachycardia. The patient's history was otherwise unremarkable. Physical exarnination on admission revealed a well-developed, well-nourished, white female in no acute distress. Heart rate was regular at 60 beats per minute with a blood pressure of $130 / 85$ torr, respiratory rate was 16 per minute, and temperature was $36.7^{\circ} \mathrm{C}$. The patient was $5^{\prime} 8^{\prime \prime}$ tall and weighed $57 \mathrm{Kg}$. Examination of the heart, chest, abdomen, and CNS were within normal limits. Haemoglobin (hgb), haematocrit, blood urea nitrogen, serum creatinine, sodium $(\mathrm{Na})$, potassium $(\mathrm{K})$, and calcium were within the normal range on admission. A standard 12 lead electrocardiogram (see Figure) showed a sinus bradycardia with a rate of 60 beats per minute. The Q-T interval was $0.44 \mathrm{~s}$ and there were prominent $U$ waves.

Hydromorphone hydrochloride $0.5 \mathrm{mg}$, hydroxyzine hydrochloride $50 \mathrm{mg}$, and glycopyrrolate $0.2 \mathrm{mg}$ intramuscularly were given two hours prior to surgery. On arrival to the preoperative holding area, we instituted continuous electrocardiographic monitoring. Diazepam $10 \mathrm{mg}$ and morphine sulfate $2.5 \mathrm{mg}$ intravenously were administered to alleviate 
the stress of preparing the patient for surgery. The patient's left racial artery was cannulated. The patient arrived in the operating room sedated but awake with a heart rate of 60 beats per minute and blood pressure of $125 / 75$ torr. The patient's nose was sprayed with ten per cent $x y$ locaine $0.25 \mathrm{ml}$ and 0.5 per cent neosynephrine $0.25 \mathrm{ml}$. Anaesthesia was induced with thiamylal sodium $450 \mathrm{mg}$ intravenously. A $7.0 \mathrm{~mm}$ endotracheal tube was placed through the nares and into the oropharynx. Succinylcholine $60 \mathrm{mg}$ was administered and the patient was ventilated with 100 per cent oxygen through the tube. Xylocaine $100 \mathrm{mg}$ was administered intravenously and the trachea sprayed with $3 \mathrm{ml}$ of four per cent xylocaine and intubated. Following intubation, anaesthesia was maintained with 60 per cent nitrous oxide and 1-2.5 per cent inspired isoflurane concentration with assisted ventilation. There was no rise in blood pressure or heart rate following intubation. The usual surgical infiltration with epinephrine containing local anaesthetics was omitted. The blood pressure rose from $110 / 80$ to $125 / 80$ torr and the heart rate from 60 to 85 beats per minute following surgical incision. The electrocardiogram revealed sinus rhythm for the duration of the surgical procedure. The patient's blood pressure remained stable at approximately $110 / 65$ torr with a heart rate of 70 beats per minute. Total crystalloid administered during surgery was $2100 \mathrm{ml}$ with an estimated blood loss of $700 \mathrm{ml}$. Intraoperative laboratory values were $\mathrm{pH} 7.37, \mathrm{PCO}_{2} 44$ torr, $\mathrm{PO}_{2}$ 202 torr, Na $140 \mathrm{meq} / \mathrm{L}, \mathrm{K} 4.1 \mathrm{meq} / \mathrm{L}$ and $\mathrm{hgb} 13.6$ $\mathrm{gm} \%$.

After cessation of anaesthesia, the patient remained intubated with her jaw wired closed. She was transported to the recovery room, breathing spontaneously. On arrival in the recovery room, her blood pressure was $117 / 76$ torr with a heart rate of 59 beats per minute and sinus rhythm on the cardiac monitor. The patient was placed on 40 per cent humidified oxygen via T-tube. Laboratory values in the recovery room were $\mathrm{pH} 7.35, \mathrm{PCO}_{2} 46$ torr, $\mathrm{PO}_{2} 175$ torr, $\mathrm{Na} 139 \mathrm{meq} / \mathrm{L}, \mathrm{K} 4.7 \mathrm{meq} / \mathrm{L}$, and hgb $12.5 \mathrm{gm} \%$. The patient remained intubated for 3.5 hours postoperatively without apparent discomfort. Xylocaine $100 \mathrm{mg}$ intravenously was given prophylactically prior to extubation. The patient's heart rate increased to 105 beats per minute following extubation, but no ventricular ectopy was noted. Propranolol $1 \mathrm{mg}$ intravenously slowed the heart

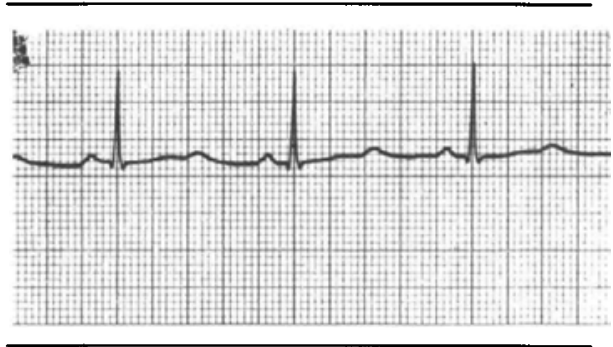

FIGURE Preoperative ECG showing sinus bradycardia at 56 beats per minute with $0.44 \mathrm{~s} \mathrm{Q}-\mathrm{T}$ interval and prominent $\mathrm{U}$ waves.

rate to 88 beats per minute. The patient remained in the recovery room with electrocardiographic monitoring for 24 hours. The blood pressure and heart rate remained stable and there was no ventricular ectopy noted. All preoperative medications were resumed. The remainder of the patient's hospital course was uneventful and she was discharged home on the third postoperative day.

\section{Discussion}

With an increasing number of patients with LQTS being identified and coming for surgery, it is important for the anaesthetist to understand this syndrome and its anaesthetic implications. Although the exact pathogenesis remains unclear, it appears an imbalance in the adrenergic stimulation of the myocardium with either an increased left sympathetic tone or decreased right sympathetic tone is the most likely etiology. ${ }^{1}$ Events leading to an increased sympathetic tone with an increase in circulating catecholamines may precipitate ventricular tachyarrhythmias in the patient with LQTS. Anaesthetic management should be directed toward minimizing sympathetic stimulation.

Several anaesthetic agents have been used in patients with LQTS. Halothane sensitizes the myocardium to circulating catecholamines and may precipitate ventricular tachyarrhythmias; hence, halothane is probably best avoided in patients with LQTS. Nitrous oxide-enflurane and nitrous oxidenarcotic techniques have been used without incident. $^{3-7}$

Because of its pharmocological properties, isoflurane should be a safe anaesthetic agent in patients with LQTS. Philbin and Lowenstein ${ }^{10}$ report no clinically significant Beta adrenergic stimulatory 
effects with isoflurane in dogs. Joas and Stevens ${ }^{11}$ report that isoflurane sensitizes the myocardium to exogenous epinephrine to a lesser extent than halothane and that as the depth of anaesthesia is increased, progressively more epinephrine is needed to induce ventricular arrhythmias. Johnston et al. ${ }^{12}$ reported similar findings during isoflurane and halothane anaesthesia in humans.

We suggest that isoflurane is a safe anaesthetic in the presence of LQTS. However, further study is required to determine the optimal anaesthetic management of these patients.

\section{References}

1 Schwartz PJ, Periti M, Malliani A. The long Q-T syndrome. Am Heart J 1975; 89: 378-90.

2 Wig J, Bali IM, Singh RG, Kataria RN, Khattri $H N$. Prolonged Q-T interval syndrome. Anaesthesia 1979; 34: 37-40.

3 Owitz S, Pratilas V, Pratila MG, Dimich I. Anaesthetic considerations in the prolonged $Q-T$ interval (LQTS): a case report. Can Anaesth Soc J 1979; 26: 50-4.

4 Brown M, Liberthson RR, Ali HH, Lowenstein E. Perioperative anesthetic management of a patient with long Q-T syndrome (LQTS). Anesthesiology 1981; 55: 586-9.

5 Callaghan ML. Nicholas AB. Sweet RB. Anesthetic management of prolonged Q-T interval syndrome. Anesthesiology 1977; 47: 67-9.

6 Ponte J, Lund J. Prolongation of the Q-T interval (Romano-Ward syndrome): anaesthetic management. Br J Anaesth 1981; 53: 1347-50.

7 O'Callaghan AC, Normandale JP, Morgan $M$. The prolonged $Q-T$ syndrome. A review with anaesthetic implications and a report of two cases. Anaesth Intensive Care 1982; X: 50-5.

8 Moss AJ, MCDonald J. Unilateral cervicothoracic sympathetic ganglionectomy for the trcatment of long QT interval syndrome. N Engl J Med 1971; 285: 903-4.

9 Ratshin RA, Hunt D, Russell RO, Jr, Rackley CE. QT-Interval prolongation, paroxysmal ventricular arrhythmias, and convulsive syncope. Ann Intern Med 1971; 75: 919-24.

10 Philbin DM, Lowenstein $E$. Lack of Beta-adrenergic activity of isoflurane in the Dog: a comparison of circulatory effects of halothane and isoflurane after propranolol administration. Br J Anaesth 1976; 48: $1165-9$.
11 Joas TA, Stevens WC. Comparison of the arrhythmic doses of epinephrine during forane, halothane and flumxene anesthesia in dogs. Anesthesiology $1971 ; 35: 48-53$.

12 Johnston RR, Eger EI, II, Wilson C. Interaction of epinephrine. Anesth Analg 1976; 55: 709-12.

\section{Résumé}

On rapporte l'observation d'um malade porteur du syndrome du $Q-T$ prolongé qui a subi de la chirurgie stomatologique de façon élective.

Les publications médicales font état de techniques d'anesthésie pour ces malades employant l'association morphinique-protoxyde d'azote protoxyde-enfurane ou protoxyde-halothane. Nous présentons ici un cas de technique employant une combinaison protaxyde d'azote et isoflurane. Nous avons l'impression que l'isofurane est un agent qu'on peut employer avec sécurité chez des malades porteurs de ce syndrome. 